\title{
Comparison of Two PCR Techniques
} Used in Amplification of Microdissected Plant Chromosomes from Rice and Wheat

Y. Zhou, H. Wang, J. Wei ${ }^{1}$, L. Cui, X. Deng, X. Wang1 and Z. Chen

Institute of Genetics, Chinese Academy of Sciences, ${ }^{1}$ Chinese Agricultural University, Beijing, P.R. China

\section{INTRODUCTION}

In studies aimed at establishing chromosome-specific DNA libraries, screening chromosome-specific sequences for the analysis of genetic linkage and physical mapping, as well as in the search for the genes coding for important traits, it is often necessary to generate large numbers of DNA fragments from defined chromosomes or chromosomal regions. Since the first report on successful cloning of sequences from specific chromosome regions of Drosophila in 1981 (15), early attempts to obtain DNA sequences or probes from specific chromosomes required enzymatic manipulation of tens to hundreds of target chromosomes collected by microdissection or flowing sorting procedures (14). However, the requirement for a large number of DNA templates and manipulation in microdrop of nanoliters has hampered the development of this technique.

In recent years, with the introduction of PCR, a minimal amount of DNA from defined chromosomal regions can be amplified using different types of primers. Linker adaptor-mediated PCR (LAM-PCR) uses specific primers (1,3, 16), and degenerate oligonucleotide primed PCR (DOP-PCR) uses degenerate primers $(13,17)$. These two types of PCR have been developed and applied widely to generate region-specific libraries from chromosomal DNA of human (6), animal (21) and plant $(3,13,18)$ samples. For LAM-PCR, chromosomal DNA is digested by frequently cutting restriction enzymes and then ligating them to synthetic adaptors that provide the primer binding sites for PCR amplification. The restriction digestion and ligation steps make it laborious and time-consuming $(1,3)$. Alternatively, DOP-PCR relies on direct amplification along the isolated chromosomes using a universal 22-mer primer in a two-step PCR $(13,17)$. The initial cycles at low annealing temperature, followed by slow temperature elevations, prime the degenerate sequences at various sites and stabilize the annealing motifs; subsequent cycles at high annealing temperature eliminate false-positive amplification. Therefore, it is technically the simplest approach for chromosome microdissection and amplification.

Here, LAM-PCR and DOP-PCR techniques were used to amplify the microdissected mitotic and meiotic chromosomal DNA from rice (O. sati$v a$ L. ssp. japonica) and wheat (Triticum aestivum L.). This is the first detailed report to compare their amplification results side by side.

\section{MATERIALS AND METHODS}

\section{Plant Materials}

Two plant species, trisomic lines of $O$. sativa L. ssp. japonica and T. aestivum L. (variety of Chinese Spring), were provided from the Institute of Genetics (Chinese Academy of Sciences, Beijing, P.R. China) and the Chinese Agricultural University (Beijing, P.R. China). 


\section{Chromosome Preparation}

The seeds of wheat and rice were germinated on moist filter paper at $20^{\circ} \mathrm{C}-25^{\circ} \mathrm{C}$. Root tips (1-2 cm long) were harvested and pretreated in ice water $\left(0^{\circ} \mathrm{C}\right)$ for $24-36 \mathrm{~h}$ to accumulate metaphase cells. In addition, rice roots were treated in $2 \mathrm{mM} 8$-hydroxyquinoline at $30^{\circ} \mathrm{C}$ in the dark for $2 \mathrm{~h}$. After pretreatment, the root tips of wheat and rice were fixed in ethanol-acetic acid (3:1) for $5 \mathrm{~min}$ and stored in $70 \%$ ethanol at $4^{\circ} \mathrm{C}$. Conversely, the rice seeds were planted in pots. When they grew to heading-stage, ears were taken off and fixed in ethanol-acetic acid (9:1) for $10 \mathrm{~min}$, followed by storage in $70 \%$ ethanol at $4{ }^{\circ} \mathrm{C}$. Mitotic and meiotic chromosome spreads of wheat and rice were prepared according to the protocol of Li and Zhang (10).

\section{Chromosome Microdissection}

After the chromosomes were viewed under a microscope, the coverslips were removed in liquid nitrogen, and the chromosomal microdissection was conducted immediately. Glass needles with tips of 1-2 $\mu \mathrm{m}$ were prepared by manually pulling the microglass rods with a diameter of 1-2 $\mathrm{mm}$. Chromosome microdissections and collection were performed on a Laborlux-2 inverted microscope with a micromanipulator (Lietz, Bonn-Bad Godesberg, Germany) under $600 \times$ magnification according to the protocol of $\mathrm{Hu}$ et al. (8). Chromosome 6B of wheat is easy to distinguish due to the site of the centromere and the presence of a satellite. Because trisomic lines of chromosomes 3,9 and 12 of rice were used in this experiment, so long as the meiotic chromosome spreads were prepared, identification and microdissection of the specific rice chromosome could be achieved. Finally, the tip of glass needle with a chromosome attached was broken into a $0.5 \mathrm{~mL}$ Eppendorf ${ }^{\circledR}$ tube.

\section{DOP-PCR}

Ten microliters of $50 \mu \mathrm{g} / \mathrm{mL}$ proteinase K (Merck, Darsmtadt, Germany) in 1× Taq buffer (Roche Molecular Biochemicals, Mannheim, Germany) were added in the tube containing microdissected chromosome and incubated at $50^{\circ} \mathrm{C}$ for $2 \mathrm{~h}$. After the proteinase $\mathrm{K}$ was heat-inactivated at $90^{\circ} \mathrm{C}$ for $25 \mathrm{~min}$, the chromosomal DNA could be directly used for amplification. Briefly, the first round of PCR amplification was performed in the same tube by adding 0.7 $\mu \mathrm{M}$ degenerate primer [5'-CCGACTCGAGNNNNNNATGTGG-3' (6MW) (17)] (CyberSyn, Beijing, P.R. China), $2.5 \mathrm{mM} \mathrm{MgCl}_{2}, 200 \mu \mathrm{M}$ dNTPs, $1 \times$ Taq buffer, 2.5 U Taq DNA polymerase (Promega, Madison, WI, USA) and UV-treated water to a final volume of $50 \mu \mathrm{L}$. After overlaying with mineral oil and denaturing at $94^{\circ} \mathrm{C}$ for $10 \mathrm{~min}$, five cycles (the first-step PCR) were run, consisting of $94^{\circ} \mathrm{C}$ for $1 \mathrm{~min}$, $30^{\circ} \mathrm{C}$ for $1.5 \mathrm{~min}$ and $72^{\circ} \mathrm{C}$ for $3 \mathrm{~min}$ with a transition time of $3 \mathrm{~min}$ from $30^{\circ} \mathrm{C}$ to $72^{\circ} \mathrm{C}$. This was followed by 25 cycles (the second-step PCR) of $94^{\circ} \mathrm{C}$ for $1 \mathrm{~min}, 57^{\circ} \mathrm{C}$ for $1 \mathrm{~min}, 72^{\circ} \mathrm{C}$ for 1.5 min with an auto-extension step of $1 \mathrm{~s} /$ cycle and a final extension at $72{ }^{\circ} \mathrm{C}$ for $10 \mathrm{~min}$. To increase the amount of product, the second-round amplification was achieved using $2 \mu \mathrm{L}$ of the first-round products as template and with only 20 cycles of the second-step PCR under the same conditions of the first round.

\section{Sau3A LAM-PCR}

A 23-mer oligonucleotide of sequence 5'-GATCCTGAGCTCGAATTCGACCC- $3^{\prime}$ and a 19-mer of sequence 5'-GGGTCGAATTCGAGCTCAG-3' (CyberSyn) were used for construction of the Sau3A linker adaptor as described by Albani et al. (1). Sau3A linker adaptors containing cloning sites of Sau3A, EcoRI and SacI were formed as shown in Table 1 . The adaptors were diluted in $1 \times$ ligase buffer and $20 \mathrm{mM}$ ATP (in UV-treated water) to a working concentration of 5 $\mathrm{ng} / \mu \mathrm{L}$. The chemicals prepared for the Sau3A linker adaptor were purchased from Promega. The isolated chromosomal DNA was treated in $20 \mu \mathrm{L}$ of proteinase $\mathrm{K}$ solution $(5 \mathrm{ng} / \mu \mathrm{L}$ in $1 \times \mathrm{T} 4$ ligase buffer) at $37^{\circ} \mathrm{C}$ for $3 \mathrm{~h}$. The proteinase $\mathrm{K}$ was inactivated at $75^{\circ} \mathrm{C}$ for 20 min. The chromosomal DNA was

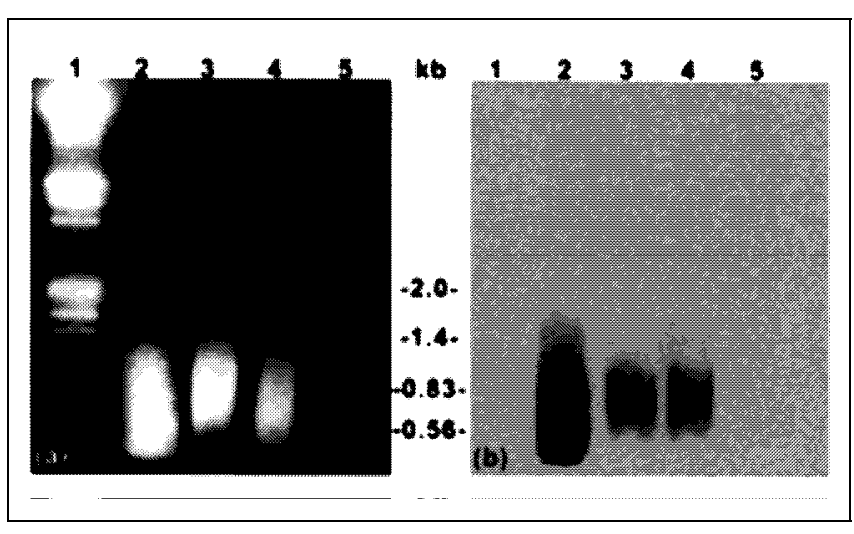

Figure 1. DOP-PCR of two mitotic rice chromosomes. (a) Second-round PCR products of the microdissected chromosomes analyzed by agarose gel electrophoresis. Lane 1, DNA size marker (Promega); lane 2, positive control for amplification; lanes 3 and 4, PCR products from the two microdissected chromosomes, respectively; lane 5, negative control for amplification. (b) Southern hybridization of the second-round DOP-PCR products with DIGlabeled genomic rice DNA.

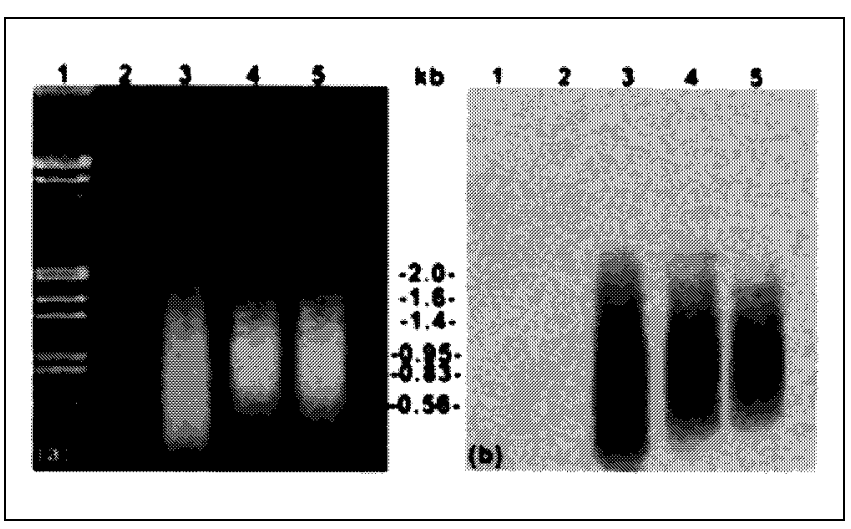

Figure 2. LAM-PCR of two mitotic rice chromosomes. (a) Second-round PCR products of the microdissected chromosomes analyzed by agarose gel electrophoresis. Lane 1, DNA size marker; lane 2, negative control for amplification; lane 3, positive control for amplification; lanes 4 and 5, PCR products from the two microdissected chromosomes, respectively. (b) Southern hybridization of the DOP-PCR products of the second round with DIGlabeled genomic rice DNA. 
then digested by Sau3A ( $0.02 \mathrm{U}$ in $1 \times$ $\mathrm{T} 4$ ligase buffer) at $37^{\circ} \mathrm{C}$ for $4 \mathrm{~h}$. Then, the Sau3A was inactivated at $70^{\circ} \mathrm{C}$ for $20 \mathrm{~min}$. Ten nanograms of prepared Sau3A linker adaptor and $1.5 \mathrm{U}$ of $\mathrm{T} 4$ DNA ligase were then added, and the ligation between the adaptor and digested chromosomal DNA was performed at $16^{\circ} \mathrm{C}$ for $16 \mathrm{~h}$. After the ligation reaction, the $\mathrm{T} 4$ ligase was inactivated at $70^{\circ} \mathrm{C}$ for $20 \mathrm{~min}$.

The first-round amplification was used in the tube containing microdissected chromosome by adding $10 \mu \mathrm{L}$ of $10 \times$ Taq buffer, $6 \mu \mathrm{L}$ of $25 \mathrm{mM} \mathrm{MgCl}_{2}$, $2 \mu \mathrm{L}$ of $10 \mathrm{mM}$ dNTPs, $250 \mathrm{ng}$ of 19 mer, $2.5 \mathrm{U}$ of Taq DNA polymerase and distilled water to $100 \mu \mathrm{L}$. After denaturing at $94^{\circ} \mathrm{C}$ for $5 \mathrm{~min}$, amplification was performed with 35 cycles of $1 \mathrm{~min}$ at $94^{\circ} \mathrm{C}, 1.5 \mathrm{~min}$ at $50^{\circ} \mathrm{C}$ and $2 \mathrm{~min}$ at $72^{\circ} \mathrm{C}$, followed by a final extension at $72^{\circ} \mathrm{C}$ for $15 \mathrm{~min}$. The second round of PCR was carried out using $2 \mu \mathrm{L}$ of the first-round products as template. The performance was the same as described above, except the cycle number was decreased to 20. To monitor the level of DNA contamination, negative control reactions without DNA were included during all stages of the microdissection and amplification procedures. Positive controls using $10 \mathrm{ng}$ of plant genomic DNA as template were also used.

\section{Southern Hybridization}

Genomic rice and wheat DNA were isolated from the leaf tissue (5). After
Table 1. Linker Adaptor of Sau3A LAM-PCR

\begin{tabular}{ccc|}
\hline Sau3A & Sacl & ECORI \\
$\downarrow$ & $\downarrow$ & $\downarrow$ \\
5'-GATCCTGAGCTC & GAATTCGACCC-3' \\
3'-GACTCGAGCTTAAGCTGGG-5' &
\end{tabular}

electrophoresis of the PCR products of microdissected chromosomes on $0.8 \%$ argarose gels at $40 \mathrm{~V}$ for $6-8 \mathrm{~h}$, the DNA was blotted on nylon membranes (Hybond $+{ }^{\circledR}$; Amersham Pharmacia Biotech, Buckinghamshire, England, UK) according to standard procedure. The probes were labeled with digoxigenin (DIG)-11-dUTP by nick translation (Roche Molecular Biochemicals). Southern hybridization and detection were performed following the instructions for the DIG DNA ${ }^{\circledR}$ labeling and detection kit (Roche Molecular Biochemicals). Furthermore, specific microsatellite primers (kindly provided by Dr. M.D. Gale of the John Innes Centre) were used to verify the origin of the amplified products.

\section{Library Construction and Characterization of Plasmid Clones}

The PCR products of wheat chromosome 6B were purified and cloned into the $\mathrm{T}$ vectors (Promega) according to the procedure described in References 4 and 20. Recombinant plasmids were isolated by alkaline lysis. Inserts were excised by digestion with EcoRI and subjected to $1.4 \%$ agarose gel. To determine the nature of the cloned inserts, plasmid DNAs $(1 \mu \mathrm{g})$ were blotted onto the Hybond+ membrane and hybridized with genomic DIG-labeled wheat DNA as described above.

\section{RESULTS}

\section{Amplification of Chromosomes from Rice by DOP-PCR and LAM-PCR}

Four chromosomes were randomly microdissected from mitotic metaphase spreads of rice without further identification. Two single chromosomes were amplified by DOP-PCR, and another two were amplified by LAM-PCR. After two rounds of amplification, the positive control and the two single microdissected chromosomes amplified by DOP-PCR yielded products ranging in size from 0.2-1.4 kb (Figure 1a, lanes $2-4)$. When hybridizing with the DIGlabeled genomic rice DNA, all products showed signals with nearly the same size range obtained in electrophoresis gel (Figure 1b, lanes 2-4). After amplification by LAM-PCR, the other two single rice chromosomes and the positive control generated smear DNA products. However, the size range was dispersed from $0.2-2.0 \mathrm{~kb}$ (Figure 2a, lanes 3-5), which was larger than that of DOP-PCR. In addition, these LAMPCR products successfully hybridized to the genomic rice DNA (Figure $2 b$, lanes 3-5), which indicated that they

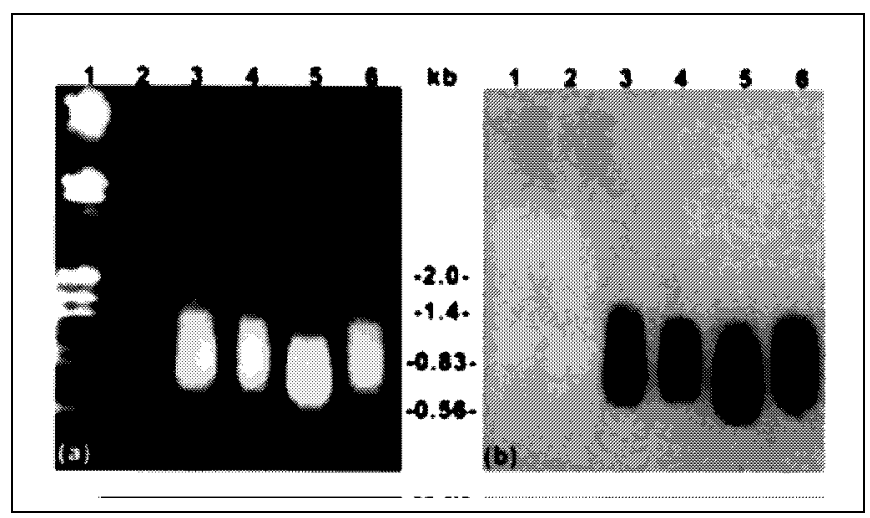

Figure 3. DOP-PCR of three meiotic rice chromosomes. (a) Second-round PCR products of microdissected chromosomes analyzed by agarose gel electrophoresis. Lane 1, DNA size marker; lane 2, negative control for amplification; lane 3, positive control for amplification; lanes 4-6, PCR products of chromosomes 3, 9 and 12. (b) Southern hybridization of the PCR products with DIG-labeled genomic rice DNA.

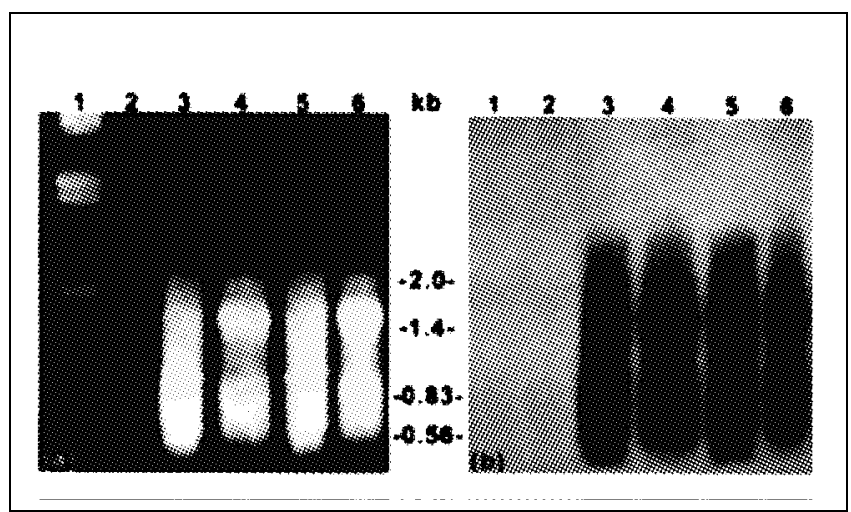

Figure 4. LAM-PCR of three meiotic rice chromosomes. (a) Secondround PCR products of microdissected chromosomes analyzed by agarose gel electrophoresis. Lane 1, DNA size marker; lane 2, negative control for amplification; lane 3, positive control for amplification; lanes 4-6, PCR products of chromosomes 3,9 and 12. (b) Southern hybridization of the PCR products with DIG-labeled genomic rice DNA. 
resulted from the rice genome. The size range and intensity of hybridization signals corresponded mostly to those presented in electrophoresis gel before hybridization. Furthermore, none of products was amplified from the negative controls after two rounds of amplification by using both PCR techniques (Figure 1, lane 5, and Figure 2, lane 2), which demonstrated that the two variant PCR methods could eliminate the amplification of extraneous DNA.

\section{Amplification of Specific Chromosomes from Rice by DOP-PCR and LAM-PCR}

After the four single chromosomes that were microdissected randomly from rice mitotic metaphase were successfully amplified by the two PCR methods, the specific chromosomes (numbers 3, 9 and 12) were microdissected from meiotic metaphase spreads of trisomic lines of rice and further amplified by DOP-PCR and LAM-PCR, respectively. In the second-round DOPPCRs, the positive control and chromosomes 3, 9 and 12, all generated smear DNA bands that ranged in size from 0.3-1.4 kb (Figure 3a, lanes 3-6). Meanwhile, the LAM-PCR products of the positive control and the three chromosomes varied from approximately 0.3-2.0 kb (Figure 4a, lanes 3-6). After hybridizing these products with the genomic rice DNA, signals were visualized from those lanes that contained chromosomal DNA, and the signals nearly corresponded with those shown in electrophoresis before hybridization (Figure 3b, lanes 3-6, and Figure 4b, lanes 3-6). However, the size range of LAM-PCR products was larger than that of the DOP-PCR products, and no products were visualized in the negative controls of the second round amplified by these two methods (Figure 3, lane 2, and Figure 4, lane 2).

\section{Amplification of Wheat Chromosome 6B by DOP-PCR and LAM-PCR}

Two chromosomes of 6B were microdissected and amplified by the two methods. After two rounds of amplification, the results obtained with both methods were nearly the same as in rice and ranged from $0.3-1.4 \mathrm{~kb}$ and $0.3-2.0 \mathrm{~kb}$ in DOP-PCR and LAMPCR (Figure 5a, lanes 4 and 5). Hybridization with the genomic wheat DNA generated signals that corresponded with those in the electrophoresis gel (Figure 5b, lanes 4 and $5)$. Contamination in the amplifications of the negative control was also eliminated (Figure 5, lane 3). Furthermore, one specific microsatellite primer (Xpsp 3009) located on chromosome 6B was used to verify the origination of the PCR products generated by the two methods. Consequently, except for the negative control (Figure 6 , lane 3 ), the $221 \mathrm{bp}$ fragment was obtained in the reactions by using the genomic wheat DNA, PCR products of the positive control and the two chromosomes as template (Figure 6, lanes 2 and 4-6), which indicated the specific sequences of chromosome 6B presented in the PCR products of microdissected chromosomes amplified by both methods.

\section{Construction and Characterization of the Microclone Libraries of Wheat Chromosome 6B}

The second-round products from chromosome 6B by LAM-PCR and DOP-PCR were purified and cloned to construct two plasmid libraries. Using a small fraction (1/1000) of the initial PCR products, 200 and 230 white colonies were obtained. This led to approximately $2.0 \times 10^{5}(\mathrm{LAM}-\mathrm{PCR})$ and $2.3 \times 10^{5}$ (DOP-PCR) recombinant clones in the two libraries. From each library, 172 recombinant clones were selected, and the inserts were released by enzyme digestion. The inserts from the library generated by LAM-PCR ranged in size from 150-2000 bp, with an aver-

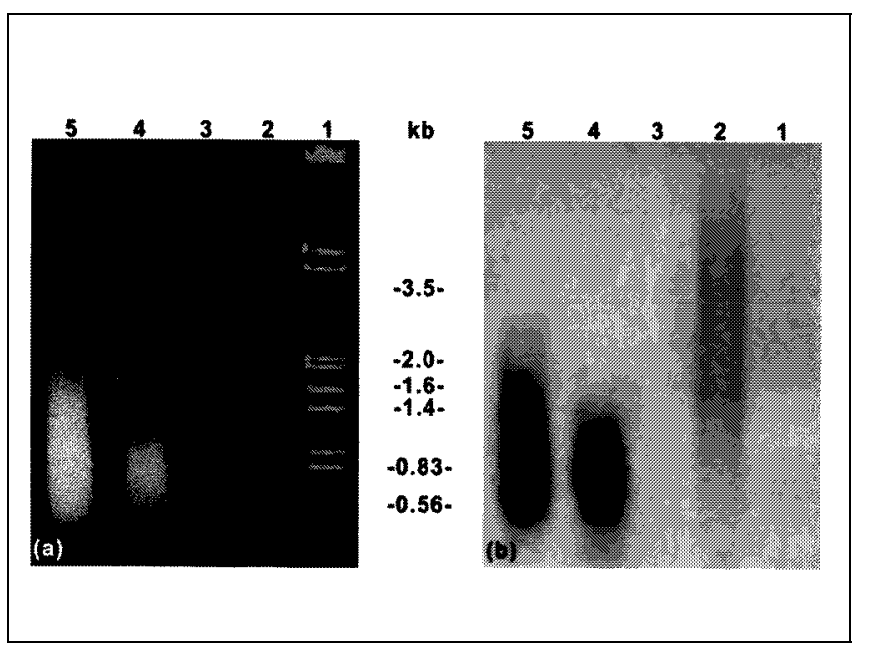

Figure 5. DOP-PCR and LAM-PCR of wheat chromosome 6B. (a) Second-round PCR products analyzed by agarose gel electrophoresis. Lane 1, DNA size marker; lane 2, $1 \mu \mathrm{g}$ of genomic wheat DNA digested with EcoRI (positive control for Southern hybridization); lane 3, negative control for amplification; lane 4, DOP-PCR products of a chromosome 6B; lane 5, LAMPCR products of a chromosome 6B. (b) Southern hybridization of the PCR products with DIG-labeled genomic wheat DNA.

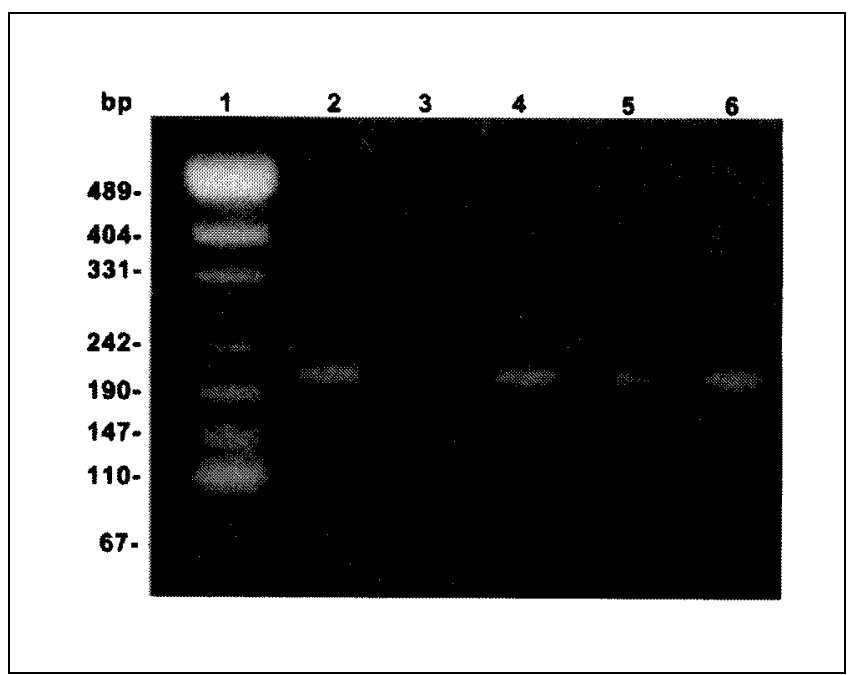

Figure 6. PCR amplification using microsatellite $\mathrm{Xpsp3009}$ as a primer to verify the origination of products from microdissected chromosomes. Lane 1, DNA size marker; lane 2, PCR products by using the wheat genomic DNA; lane 3, DNAs from the negative control; lane 4, DNAs from the positive control; lane 5, DOP-PCR products of a chromosome 6B; lane 6, LAM-PCR products of a chromosome $6 \mathrm{~B}$ as templates. 
age size of $900 \mathrm{bp}$. The insert size of the library of DOP-PCR was 300-1400 bp, with an average size of $490 \mathrm{bp}$ (data not shown). Dot blot analysis was further carried out to estimate the nature of the inserts. Of 116 recombinant clones, $52 \%$ and $47 \%$ of clones that showed obvious hybridization signals belonged to the high copy sequences in the LAMPCR and DOP-PCR libraries, respectively (Figure 7, a and b).

\section{DISCUSSION}

In this report, microdissected mitotic and meiotic rice chromosomes and wheat chromosome $6 \mathrm{~B}$ were successfully amplified by DOP-PCR and LAM-PCR. Regardless of variant plant species and chromosome, reasonable smear DNAs from approximately 0.3$1.4 \mathrm{~kb}$ or $0.3-2.0 \mathrm{~kb}$ were discovered in DOP-PCR or LAM-PCR, respectively.
These results showed that the two PCR methods were reliable and the amplification results were reproducible. For several years, both PCR techniques have been used to amplify chromosomal DNA from a wide range of species including many plants $(1,3,4$, $11,16,18-20)$, which could mean that both techniques are species-independent. However, based on our experiences, the DOP-PCR showed high sensitivity to many parameters in PCRs and chromosome preparations.

The concentration of primer and salt $(\mathrm{Mg}+)$, the units of Taq DNA polymerase and the annealing temperature adopted proved to be key factors that affect amplification (17). Thus, DOP-PCR is more difficult to carry out routinely than LAM-PCR. Actually, the DOPPCR procedure adopted here has been improved based on a number of experiments. Without optimum parameters, ideal amplification of chromosomal
DNA from some plant species was difficult to obtain by DOP-PCR. If small modifications were performed in DOPPCR under these conditions, microdissected chromosomes from rye, soybean and Vivia faba could not be amplified stably or even failed (data not shown) (e.g., diluting proteinase $\mathrm{K}$ at $500 \mu \mathrm{g} / \mathrm{mL}$ in $10 \mathrm{mM}$ Tris-Cl, $\mathrm{pH} 8.0,10 \mathrm{mM} \mathrm{NaCl}$, $0.1 \%$ SDS rather than at $50 \mu \mathrm{g} / \mathrm{mL}$ in $1 \times$ PCR buffer, and decreasing the annealing temperature from $57^{\circ} \mathrm{C}$ to $55^{\circ} \mathrm{C}$ ). In comparison, LAM-PCR showed less sensitivity to small modifications.

One of the difficulties in handling the DOP-PCR is finding the best method to eliminate extraneous DNA contamination. In fact, it has been shown that extraneous DNA contamination is one of major limitations associated with these techniques when amplifying a minimal amount of DNA. Although this problem can be significantly reduced with more care taken in autoclaving the equipment 


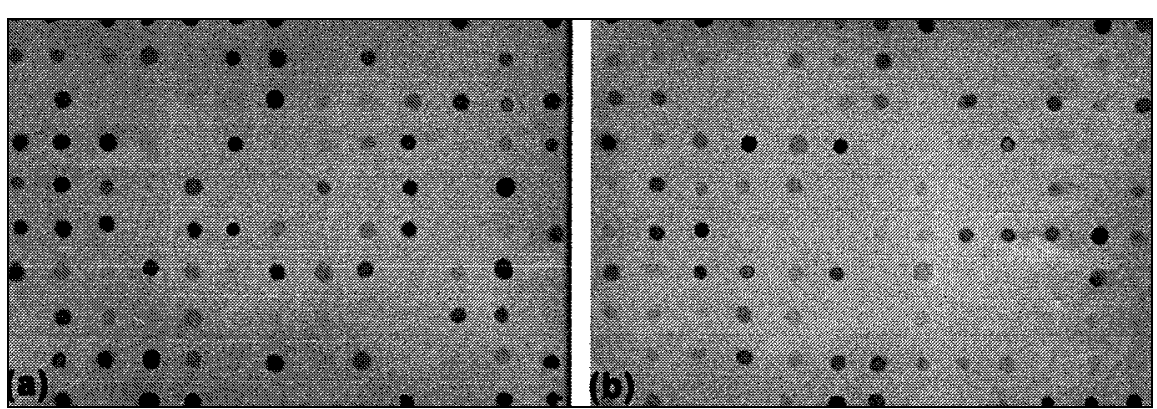

Figure 7. Dot blotting hybridization of $\mathbf{1 1 6}$ plasmid clones with the DIG-labeled wheat genomic DNA. (a) Recombinant clones selected from the library of chromosome 6B constructed by LAM-PCR. (b) Recombinant clones selected from the library of chromosome 6B established by DOP-PCR.

and treating solutions with UV irradiation, unexpected contaminations will often come from enzyme or solution preparations supplied by different companies (12). Since DOP-PCRs require fewer steps and chemical components, the contamination problems could be avoided. However, the low annealing temperature and the single nonspecific degenerate primer used in DOP-PCR make contamination difficult to eliminate completely. Negative controls were set up to monitor contamination. If any products were obtained in negative controls, the amplifications of chromosomes could be seen as failures, and the products would need to be discarded. Until recently, the only approaches to solve this problem were screening various enzyme preparations or reducing the number of different enzyme reactions involved. Alternatively, a decrease in the quantity of template DNA (the number of dissected chromosomes) may decrease the likelihood of potential contamination. In our study, in both LAM and DOP-PCR, only a single target chromosome was used as template, and the contamination was effectively controlled.

Here, the products amplified by LAM-PCR were generally larger than those amplified by DOP-PCR. This advantage was reported in other plants $(3,4,11,19,20)$ and is a significant aspect in assessing the quality of amplification and of microclone libraries $(3,21)$. Because the optimal size for RFLP analysis in higher plants has been usually suggested to be greater than 300 bp (9), larger-sized amplified fragments are expected. Because of this, LAM-PCR has the advantage over 
DOP-PCR, though short sequences appear to be more stable while cloning. This phenomenon is probably caused by the difficulty in amplifying large sequences by random and nonspecific primers adopted in DOP-PCR.

After analysis of the two libraries of wheat chromosome 6B, $47 \%$ and $52 \%$ of clones belonged to the high copy sequences. Compared with the natural repetitive DNA sequences of about $80 \%$ in the wheat nuclear genome, the two libraries were abundant in low or single copy sequences. Actually, it has been confirmed that chromosome-specific libraries generated by the both methods are abundant in low or single copy sequences $(3,11,16,18)$ but were the result of different methods. In LAM-PCR, the use of cytosine methylation-sensitive restriction endonucleases (Sau3A, NotI, $M o b I$ and HpaII) to digest chromosome DNA and the amplification with specific primers of appropriate adaptors might be expected to rule out repetitive sequences (3). However, in DOP-PCR, it is the amplification that selects against repetitive sequences directly. The preferential selection for low copy and chromosome-specific sequences by DOPPCR was noticed in the amplification of flow-sorted chromosomes of tomato (2), microdissected B-chromosomes of rye (7) and chromosomes of wheat (11). This characteristic makes the DOP-PCR products suitable as probes for painting chromosomes throughout their entire length (18). On the other hand, preferential amplification of some sequences may cause some DNA sequences to be missing and may decrease the coverage of the microclone libraries. Although this problem also exists in LAM-PCR, it can be overcome by using different combinations of restriction enzymes and adaptors to generate genomic libraries that cover a whole chromosome.

In conclusion, we compared the two PCR techniques in the aspects of exogenous contamination, optimization of PCR procedure and the length and nature of amplified sequences. Although LAM-PCR and DOP-PCR are now the two major methods to generate large numbers of DNA fragments from defined chromosomes, there is still a long way to go before they become routine procedures in chromosome microdissection and microcloning technology.

\section{ACKNOWLEDGMENTS}

We thank Dr. Zanmin Hu for his kind help in chromosome microdissection, and Prof. Rofu Du and Dr. Yuhong Tang for their critical reading of the manuscript.

\section{REFERENCES}

1.Albani, D., M.J. Cote, K.C. Armstrong, Q. Chen, A. Segal and L.S. Robert. 1993. PCR amplification of microdissected wheat chromosome arms in a simple single tube reaction. Plant J. 4:899-903.

2.Arumuganathan, K., G.B. Martin, H. Telenius, S.D. Tanksley and E.D. Earle. 1994. Chromosome 2-specific DNA clones from flow-sorted chromosomes of tomato. Mol. Gen. Genet. 242:551-558.

3.Chen, Q. and K.C. Armstrong. 1995. Characterization of a library from a single microdissected oat (Avena sativa L.) chromosome. Genome 38:706-714.

4.Dang, B.Y., Z.M. Hu, Y.H. Zhou, L.H. Cui, L.L. Wang, L.C. Li and Z.H. Chen. 1998. Construction of single-chromosome DNA library from Lilium regale Wilson. Chin. Sci. Bull. 43:434-438.

5.Fu, R.Z., Y.R. Sun and S.R. Jia. 1994. The techniques handbook of plant genetic transformation. Science and Technology Press of China, Beijing. p. 135.

6.Guan, X.Y., P.S. Meltzer and A.C. Burgess. 1995. Coverage of chromosome 6 by chromosome microdissection: generation of 14 subregion-specific probes. Hum. Genet. 95:637-640.

7.Houben, A., R.G. Kynast, U. Heim, H. Hermann, R.N. Jones and J.W. Forster. 1996. Molecular cytogenetic characterization of the terminal heterochromatic segment of the Bchromosome of rye (Secale cereale). Chromosoma 105:97-103.

8.Hu, Z.M., L.H. Cui, L.L. Wang, Z.H. Chen and L.C. Li. 1997. Isolation of single chromosome and chromosomal fragments of Lilium regale. Acta Genet. Sin. 24:278-281. (Chinese only)

9.Jahoor, A., G. Backes, A. Graner, R.G. Herrmann and G. Fischbeck. 1991. Development of RFLP markers for barley. Plant Breed. 107:73-76.

10.Li, M.X. and Z.P. Zhang. 1996. Chromosomes of Crops and Relative Research Techniques. Chinese Agriculture Press, Beijing. (Chinese only)

11.Liu, B., G. Segal, J.M. Vega , M. Feldman and S. Abbo. 1997. Isolation and characterization of chromosome-specific DNA sequences from a chromosome arm genomic library of common wheat. Plant J. 11:959-965.

12.Meltzer, P.S., X.Y. Guan, J. Zhang and J.M. Trent. 1995. In R.S. Verma and A. Babu (Eds.), Human Chromosomes: Principles and Techniques. McGraw-Hill. Health Profession Division, New York, 2nd:1271-1279.

13.Pich, U., A. Houben, J. Fuchs, A. Meister and I. Schubert. 1994. Utility of DNA amplified by degenerated oligonucleotide-primed
PCR (DOP-PCR) from the total genome and defined chromosomal regions of field bean. Mol. Gen. Genet. 243:173-177.

14.Sandery, M.J., J. Forster, S.R. Macadam, R. Blunden, R.N. Jones and S.D.M. Brown. 1991. Isolation of a sequence common to Aand B-chromosomes of rye (Secale cereale) by microcloning. Plant Mol. Biol. Rep. 9:21-30.

15.Scalenghe, F., E. Turco, J.E. Edstrom, V. Pirrotta and M.I. Melli. 1981. Microdissection and cloning of DNA from a specific region of Drosophila melanogaster polytene chromosomes. Chromosoma 82:205-216.

16.Stein, N., N. Ponelies, T. Musket, M. McMullen and G. Weber. 1998. Chromosome microdissection and region-specific libraries from pachytene chromosomes of maize ( $\mathrm{Zea}$ mays L.). Plant J. 13:281-289.

17.Telenius, H., N.P. Carter, C.E. Bebb, M. Nordenskjold, B.A.J. Ponder and A. Tunnacliffe. 1992. Degenerate oligonucleotideprimed PCR: general amplification of target DNA by a single degenerate primer. Genomics 13:718-725.

18.Vega, J.M., S. Abbo, M. Feldman and A.A. Levy. 1994. Chromosome painting in plants: in situ hybridization with a DNA probe from a specific microdissected chromosome arm of common wheat. Proc. Natl. Acad. Sci. USA 91:12041-12045.

19.Wang, H., Y.H. Zhou, B.Y. Dang, Z.M. Hu, L.L. Wang, L.C. Li and Z.H. Chen. 1998. Chromosome microdissection by laser microbeam, chromosomal fragment isolation and amplification in vitro in barley (Hordeum vulgare L.). Chin. Sci. Bull. 43:851-855.

20.Zhou, Y.H., B.Y. Dang, Z.M. Hu, L.H. Cui, L.C. Li, Z.H. Chen. 1998. Microdissection and PCR amplification of single soybean chromosome. Acta Botan. Sin. 40:144-150. (Chinese only)

21.Zimmer, R., A. Haberfeld and A.M.V. Gebbins. 1997. Microisolation of the chicken Z chromosome and construction of microclone libraries. Genome 40:865-872.

Received 30 March 1999; accepted 30 November 1999.

\section{Address correspondence to:}

Zhenghua Chen

Institute of Genetics

Chinese Academy of Sciences

Beijing, 100101

P.R. China

Internet: zhchen@public.east.cn.net 